\title{
A method to detect and quantitate the expression of normal versus mutant H-ras transcripts at codon 12
}

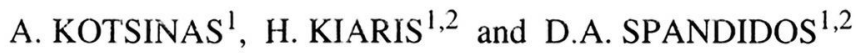 \\ ${ }^{1}$ Institute of Biological Research and Biotechnology, National Hellenic Research Foundation, \\ 48 Vas. Constantinou Ave., Athens 11635; ${ }^{2}$ Medical School, University of Crete, Heraklion, Greece
}

Contributed by D.A. Spandidos, June 16, 1994

\begin{abstract}
We describe a PCR based method for qualitative and quantitative analysis of the H-ras gene. For qualitative analysis the aim was to detect codon 12 point mutations at transcriptional and genomic levels by a non-radioactive RFLP assay. Quantitative analysis was achieved by constructing an internal competitor with the same primer site requirements and sequence homology to the $\mathrm{H}$-ras 1 gene. The internal control was cloned into an expression vector allowing quantification at the genomic as well as transcriptional level. Two cell lines harbouring normal and T24 H-ras 1 respectively, were employed as controls for qualitative and quantitative analysis. Theoretical implications of competitive quantification are also evaluated for increased estimation efficiency.
\end{abstract}

\section{Introduction}

ras oncogenes have been found to play an important role in the multistep process of carcinogenesis. ras gene activation either through structural modifications and/or alterations of gene expression levels can lead to loss of normal control of cell growth and differentiation $(1,2)$.

Activation through point mutations of ras genes has been found to be an early and influential event during the initiation and progression of many cancers (1-4). However, recent work has emphasised the importance of gene dosage on the phenotype of cells bearing ras oncogenes (5). Furthermore, analysis of expression levels in late stages of colorectal tumours, has shown that there is an imbalance between mutant versus normal K-ras alleles at the RNA level (6).

These observations suggest that the capacity of ras to influence tumorigenesis is not restricted to point mutational activation affecting early stages of malignant progression. On

Correspondence to: Professor D.A. Spandidos, Institute of Biological Research and Biotechnology, National Hellenic Research Foundation, 48 Vas. Constantinou Ave., Athens 11635 , Greece

Key words: H-ras1, competitive RT-PCR, quantitative RT-PCR, PCR-RFLP the contrary, altered ratios of ras genes at either gene level, transcriptional or post-transcriptional level can also apparently affect progression in later stages of tumour development.

We have designed a reverse transcription-competitive PCR-RFLP assay in order to detect codon 12 point mutations at the DNA and RNA level and also to quantitate differences between the expression of mutant and normal $\mathrm{H}$-ras 1 alleles. This allows the detection not only of early activating mutations, but also changes in gene dosage during subsequent stages of tumour evolution.

The PCR products from DNA and RNA amplifications are $419 \mathrm{bp}$ and $151 \mathrm{bp}$ respectively. Two natural MspI restriction sites present in both PCR products of the normal gene, facilitate the detection of codon 12 mutations and discrimination between normal and mutant alleles (7).

For quantitative studies a construct derived from the DNA PCR product after internal deletion of $187 \mathrm{bp}$, was cloned into an expression vector. Products from this DNA could thus be distinguished by size from those produced from genomic DNA and cDNA. After in vitro transcription the cRNA is employed as an internal standard during the RTPCR quantitative assay, while the construct itself is used as a standard for genomic DNA quantitation. The simultaneous coamplification of the standard corrects for the differences in the PCR amplifications which can occur in each test tube. This is simplified by the use of a single pair of PCR primers and results in competitive coamplification of all types of transcripts.

The method described in this report was applied to cell lines: RFHO6N1 and RFAGT1 $(8,9)$. RFHO6N1 and RFAGT1 were obtained after transfecting high copy numbers of normal and T24 H-ras 1 gene respectively into $208 \mathrm{~F}$ rat fibroblasts, both express high levels of ras p21 $(8,9)$. We were able to detect the specific type of H-ras 1 allele present in each cell line and to estimate the $\mathrm{H}$-ras 1 copy numbers both at genomic and transcriptional level in each cell line respectively.

\section{Materials and methods}

Cell lines. RFHO6N1 and RFAGT1 are 208F recipient cells and have been described elsewhere $(8,9)$. They were obtained after transfection of normal and T24 BamHI H-ras 1 fragment respectively and express high levels of ras $\mathrm{p} 21$ protein. 


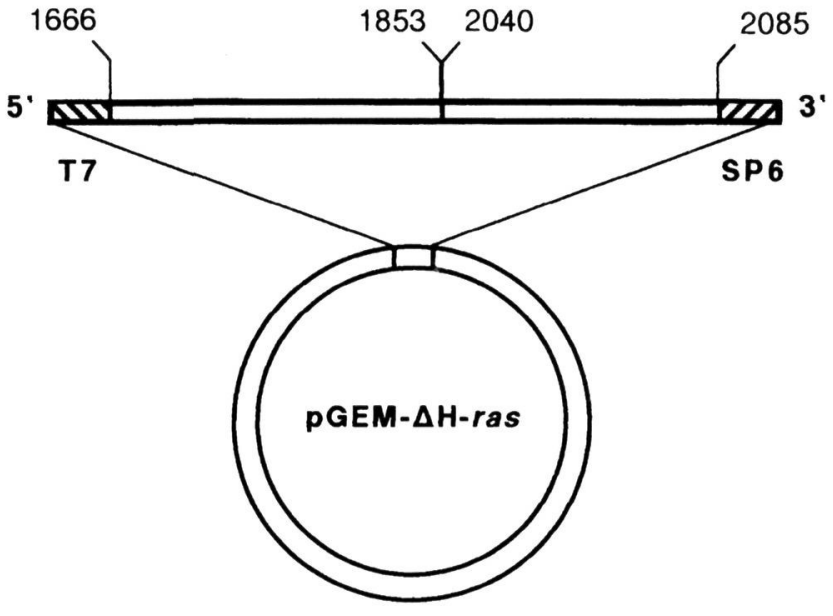

Figure 1. Schematic representation of the recombinant plasmid employed as competitor in quantification assays. Nucleotide numbering of the competitor sequence as per Capon et al (14). The competitor was derived from a $419 \mathrm{bp}$ PCR product after deletion at position 1853-2040 of an internal fragment with PstI.

DNA and RNA extraction. DNA was extracted from the cells by proteinase $\mathrm{K}$ (Boehringer) and phenol/chloroform treatment as previously described (10). RNA was extracted by the RNazolB kit (China-Biotex) as previously described (5). The quality and quantity of RNA and DNA was assessed by spectrophotometry at $260 \mathrm{~nm}$ and $280 \mathrm{~nm}$.

Recombinant $\mathrm{H}$-ras plasmid. The transcription vector pGEM$\Delta \mathrm{H}$-ras was engineered by cloning a $232 \mathrm{bp}$ fragment into the Sall site of pGEM4 (Promega). The 232bp fragment was derived from a genomic DNA PCR product after internal deletion of 187bp with PstI (NEB) Fig. 1.

In vitro transcription. The transcription plasmid pGEM- $\Delta \mathrm{H}-$ ras was linearized with EcoRI so as to yield RNA of about 295 bp. Following in vitro transcription with T7 RNA polymerase (Gibco-BRL) RNA was purified as previously described and assessed qualitatively by agarose gel electrophoresis and spectrophotometry.

PCR amplification. PCR amplification was performed in 50 $\mu 1$ reactions (75 mM Tris- $\mathrm{HCl} \mathrm{pH} 9.0,20 \mathrm{mM}\left(\mathrm{NH}_{4}\right)_{2} \mathrm{SO}_{4}$, $1.5 \mathrm{mM} \mathrm{MgCl}, 0.01 \%$ Tween (w/v), $200 \mu \mathrm{M}$ dNTPs) with $100 \mathrm{ng}$ of each primer and $0.25 \mathrm{U}$ Taq polymerase (Advanced Biotechnologies). The amplimer sequences were:

5'-GACGGAATATAAGCTGGTGG-3' and

5'-AGGCACGTCTCCCCATCAAT-3'.

The PCR program consisted of $50 \mathrm{sec}$ at $94^{\circ} \mathrm{C}, 35 \mathrm{sec}$ at $62^{\circ} \mathrm{C}$ and $35 \mathrm{sec}$ at $72^{\circ} \mathrm{C}$ for a total of 25 cycles.

$R T$-PCR amplification. Reverse transcription was performed in a $50 \mu \mathrm{l}$ reaction $(10 \mathrm{mM}$ Tris- $\mathrm{HCl} \mathrm{pH} 8.3,50 \mathrm{mM} \mathrm{KCl}, 1$ $\mathrm{mM} \mathrm{MnCl} 2,200 \mu \mathrm{M}$ dNTPs) with $200 \mathrm{ng}$ of antisense primer and $2.5 \mathrm{U}$ Tth polymerase. The reactions were incubated at $70^{\circ} \mathrm{C}$ for $10-15 \mathrm{~min}$. PCR amplification of cDNA was performed by supplementing $50 \mu \mathrm{l}$ of: $75 \mathrm{mM}$ Tris- $\mathrm{HCl} \mathrm{pH}$ 9.0, $20 \mathrm{mM}\left(\mathrm{NH}_{4}\right)_{2} \mathrm{SO}_{4}, 1.5 \mathrm{mM} \mathrm{MgCl} 2,0.01 \%$ Tween (w/v), $0.75 \mathrm{mM}$ EGTA and $200 \mathrm{ng}$ of sense primer to the RT reaction, following the same PCR program as described above.

RFLP analysis. $15 \mu \mathrm{l}$ of the PCR reactions were subjected to MspI (NEB) digestion (20U) at a final volume of $30 \mu \mathrm{l}$ at $37^{\circ} \mathrm{C}$ for $4 \mathrm{~h}$. The products were electrophoresed through a $3 \%$ agarose gel (BRL). Gels were stained with ethidium bromide and photographed on an ultraviolet transilluminator.

DNA quantitation. $100 \mathrm{ng}$ of genomic DNA (from RFAGT1 and RFHO6N1 cell lines) were mixed with tenfold sequentially diluted EcoRI linearized pGEM- $\Delta \mathrm{H}$-ras plasmid ( $5 \mathrm{ng}, 500 \mathrm{pg}, 50 \mathrm{pg}, 5 \mathrm{pg}, 0.5 \mathrm{pg}$ ) respectively. PCR amplification was performed as previously described. Products were separated on $6 \%$ polyacrylamide gels and silver stained. Gels were scanned on a Personal Densitometer ${ }^{\mathrm{TM}}$ SI (Molecular Dynamics) (11). Data obtained from densitometric analysis were statistically analysed on a Macintosh computer with Cricket Graph (ver. 1.3.2).

RNA quantitation. Total RNA from RFAGT1 and RFHO6N1 cell lines was twofold serially diluted $(1 \mu \mathrm{g}, 0.5 \mu \mathrm{g}, 0.25 \mu \mathrm{g}$, $0.1 \mu \mathrm{g}, 0.05 \mu \mathrm{g})$ respectively and mixed with $0.1 \mathrm{ng}\left(6.4 \times 10^{8}\right.$ copies) cRNA. RT-PCR was performed as previously described. Products were run on 6\% polyacrylamide gel and silver stained. Densitometric and statistical analysis were performed as for DNA quantitation.

\section{Results}

$P C R$ amplification. For the specific detection and amplification of H-ras transcripts, a pair of primers was designed using an exon connection strategy. The amplified cDNA segment is of $151 \mathrm{bp}$ and consists of exon 1 and the 5' end of exon 2 (Fig. 2B, 2D). The same primer pair enables amplification from genomic DNA, but yields a different sized product of $419 \mathrm{bp}$, since the intervening intron is also amplified (Fig. 2A, 2C). Thus after RT-PCR amplification it is also possible to check for the presence of contaminating DNA in the RNA preparations.

Detection of codon 12 mutations. Detection of codon 12 mutations is accomplished by the use of a natural occurring RFLP in the PCR products of the normal and mutated gene and transcripts. In normal H-ras 1 alleles, codon 12 is part of a MspI restriction site. Mutations at codon 12 inactivate this MspI site, allowing discrimination of mutant alleles from wild type $\mathrm{H}$-ras 1 alleles (Fig. 2). A second natural MspI site at the $3^{\prime}$ end of PCR products, present in both cDNA as well as genomic DNA, is conserved and serves as a control for the efficiency of digestion at the 5 ' end site, discriminating at the same time the digested products from the undigested ones (Fig. 2).

PCR amplification of H-ras 1 cDNA as well as genomic DNA from the RFAGT1 and RFHO6N1 cell lines resulted in the expected product sizes respectively (Fig. 2). Under the same conditions RNA and DNA from the parental cell line 208F showed negative results demonstrating the high specificity of the primers for the human sequence. 
A. genomic DNA templates

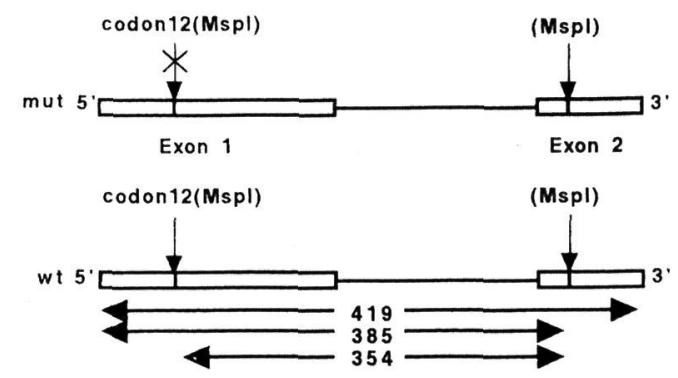

B. cDNA templates

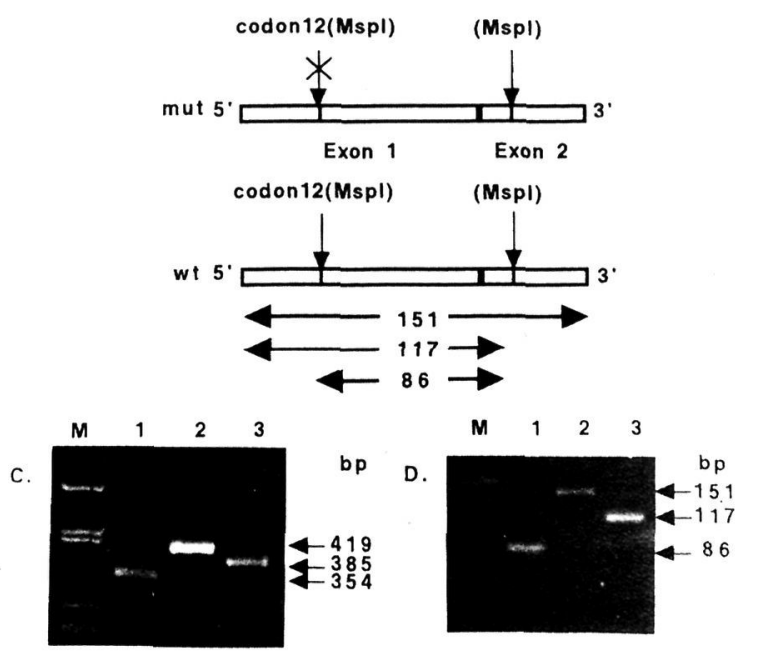

Figure 2. Schematic representation of H-ras DNA and cDNA amplicons before and after RFLP analysis. A. Undigested DNA amplicons are 419bp in size while normal and mutant H-ras RFLP products are $354 \mathrm{bp}$ and $385 \mathrm{bp}$ respectively. B. For cDNA amplicons the equivalent sizes are: $151 \mathrm{bp}$ for undigested PCR product, 117bp for mutant H-ras RFLP product and $86 \mathrm{bp}$ for normal H-ras RFLP product. C. and D. Representative results of application of the RT-PCR-RFLP and PCR-RFLP assays from the RFHO6N1 and RFAGT1 cell lines. $\mathrm{Cl}=$ normal $\mathrm{H}$-ras DNA amplicon, $\mathrm{C} 2=$ undigested DNA amplicon, C3= mutant $\mathrm{H}$-ras DNA amplicon, D1= normal $\mathrm{H}$-ras cDNA amplicon, D2= undigested cDNA amplicon, D3= mutant $\mathrm{H}$ ras cDNA amplicon, $\mathrm{M}=$ marker.

RFLP analysis of genomic DNA amplicons from RFHO6N1 revealed the presence of only normal human $\mathrm{H}$ ras 1 alleles, while in the RFAGT1 cell line only mutant $\mathrm{H}$ ras 1 was detected (Fig. 2). In addition RFLP analysis of cDNA amplicons showed the expression of the specific $\mathrm{H}$ ras type present in each cell line.

Quantitation by ratio. To obtain quantitative measurements of H-ras 1 gene and transcript copies, a competitive assay was employed. An internal control was constructed and cloned in an expression vector. The internal control was derived from a genomic DNA PCR product after internal deletion with PstI of a 187 bp fragment (Fig. 1) (12). Despite the difference in size, the internal control has the same primer annealing sites as H-ras $1 \mathrm{cDNA}$ and genomic DNA enabling competitive PCR reactions to be performed.

i) The construct itself was employed in genomic DNA quantitation assays for the determination of H-ras 1 copy number present in each cell line. Tenfold dilution series of plasmid DNA were prepared over a large input range of $5 \mathrm{ng}$ to $0.5 \mathrm{pg}$ and spiked separately with $100 \mathrm{ng}$ of genomic DNA from each cell line.
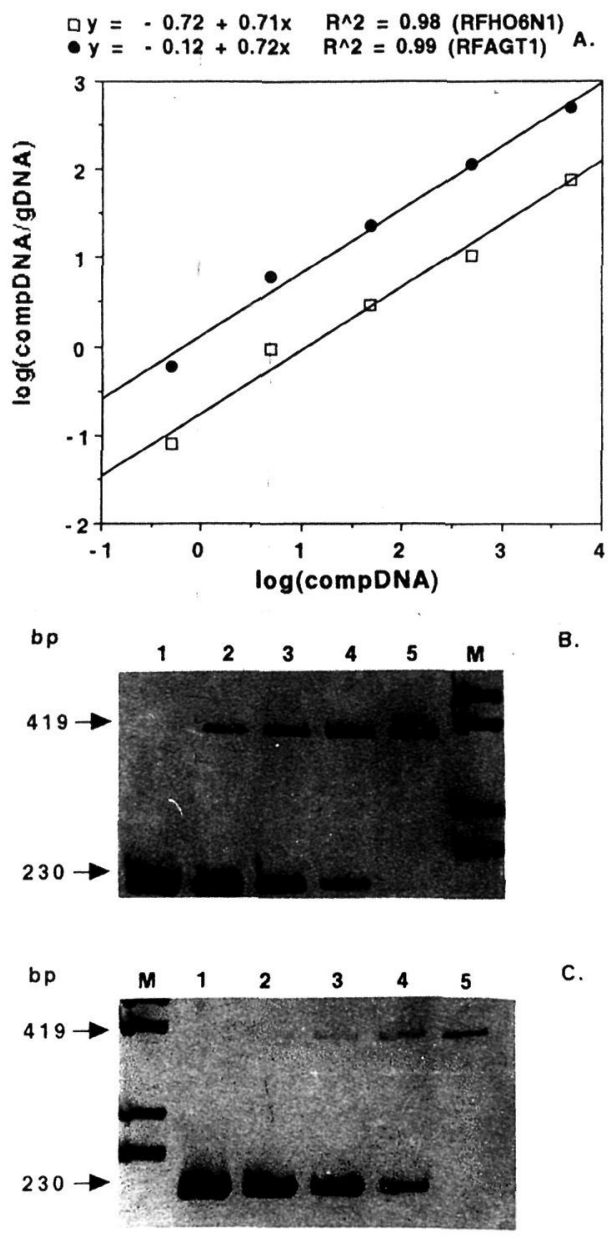

Figure 3. Comparative quantitation results for H-ras copy number present in the genomes of RFHO6N1 and RFAGT1 cell lines. A. Log plots of PCR products versus tenfold serial dilutions of competitor vector ( $5 \mathrm{ng}-0.5 \mathrm{pg}$ ). The RFHO6N1 cell line exhibited approximately 7-fold higher number of $\mathrm{H}$-ras copies in the genome than RFAGT1 cells. B. and C. Representative results from quantitative PCR assays for RFHO6NI (panel B) and RFAGT1 (panel C) cells. $M=$ marker, lanes $1-5=5 \mathrm{ng}-0.5 \mathrm{ng}$ competitor vector/ $100 \mathrm{ng}$ genomic DNA.

The log ratios of densitometric values of competitor to genomic DNA after PCR amplification were plotted against the $\log$ values of diluted construct amounts. Regression analysis showed that the data fit closely with linear lines in both cell lines (Fig. 3). The linear relationships were preserved over a wide range of PCR cycle numbers, but in order to keep the slopes of the equations closer to unity as predicted by the theoretical analysis of PCR amplification (13), the optimum conditions described in Methods were employed.

The equations for the standard curves of RFHO6N1 and RFAGT1 cell lines were $y=0.71 x-0.72\left(R^{2}=0.98\right)$ and $y=0.72 x-0.12\left(R^{2}=0.99\right)$ respectively. From the equivalence points $(y=0)$ for each cell line it was estimated that the RFHO6N1 cell line $\left(6.3 \times 10^{6}\right.$ copies/100 ng genomic DNA) had received approximately 7-fold higher copy number of $\mathrm{H}$ ras than the RFAGT1 cell line $\left(91.5 \times 10^{4}\right.$ copies/100 $\mathrm{ng}$ genomic DNA).

ii) In order to obtain similar data at the RNA level run-off transcripts were obtained after in vitro transcription from the recombinant vector (as described in Methods). Two-fold serial dilution series of totRNA from each cell line was 

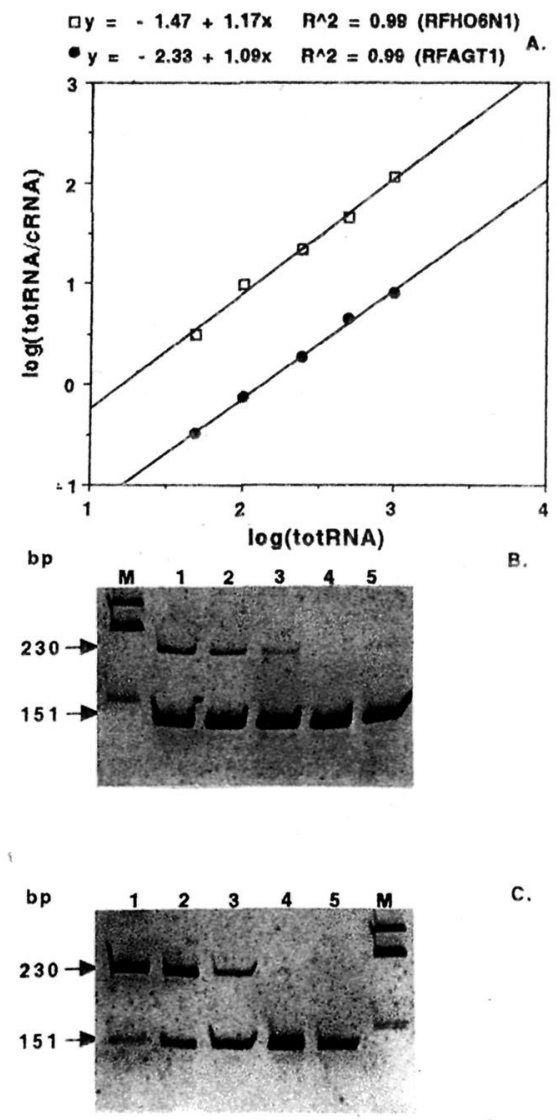

Figure 4. Comparative quantitation results for $\mathrm{H}-$ ras 1 transcriptional expression level of RFHO6N1 and RFAGT1 cell lines. A. Log plots of twofold serially diluted totRNA $(1 \mu \mathrm{g}-0.05 \mu \mathrm{g})$ versus $100 \mathrm{pg}\left(6.4 \times 10^{8}\right.$ copies) cRNA. The level of expression of H-ras is higher in RFHO6N1 cells since 7.5-fold higher amount of totRNA from RFAGT1 cells is necessary to obtain similar level of H-ras transcripts as per RFHO6N1 cells. B. and C. Representative results from quantitative RT-PCR assays for RFHO6N1 (panel B) and RFAGT1 (panel C) cells. M=marker, lanes 1-5=1 $\mu \mathrm{g}-0.05 \mu \mathrm{g}$ tot RNA/ 100 pg cRNA.

prepared in the range of $1 \mu \mathrm{g}-0.05 \mu \mathrm{g}$. The serial dilutions were spiked with $100 \mathrm{pg}$ of $\mathrm{cRNA}$ and the mixtures were subjected to RT-PCR amplification.

Graphical representations of log-log plots were obtained and linear regression analysis was performed (Fig. 4). Linear relationship was observed over a wide range of PCR cycle numbers, but in order to keep the slope of the equations close to unity high PCR cycling numbers were avoided so as to keep the reactions in the $\log$ phase of amplification.

The standard curves for RFHO6N1 and RFAGT1 cell lines were $y=1.17 x-1.47\left(R^{2}=0.99\right)$ and $y=1.09 x-2.33$ $\left(R^{2}=0.99\right)$ respectively. From the equivalence points of the equations it was estimated that the level of $\mathrm{H}$-ras 1 transcripts was approximately 7.5 -fold higher in RFHO6N1 $\left(3.5 \times 10^{12}\right.$ copies/ $\mu \mathrm{g}$ totRNA) than in RFAGT1 $\left(0.46 \times 10^{12}\right.$ copies/ $\mu \mathrm{g}$ totRNA) cells. This result is in agreement with the difference in the copy number of $\mathrm{H}$-ras 1 present in the genome of each cell line.

\section{Discussion}

We have described a PCR based method to enable investigation of H-ras 1 alterations both at genomic and transcriptional level. Our aim is to detect qualitative as well as quantitative changes in $\mathrm{H}$-ras 1 function in tumours.

Point mutational activation of the $\mathrm{H}$-ras 1 gene is known to be an early event in the pathology of certain tumours (1-3). The presence of such mutations can be detected by exploiting natural RFL.P sites present at the nucleotide level of H-ras 1 $(6,14)$. We have designed the primers described in this report with the following in mind:

i) Potential detection of CDNA and genomic DNA H-ras 1 amplicons by the same pair of primers. The exon connection strategy employed for the detection of H-ras 1 amplicons enables discrimination from the genomic DNA amplicons due to the presence of the intervening intron. Thus, both types of PCR products can easily be distinguished by size fractionation after electrophoresis.

ii) RFLP detection of codon 12 mutation in both H-ras 1 amplicon types. The primers were designed in order to preserve and make use of the existing natural MspI site which includes codon 12. Furthermore, the antisense primer was positioned downstream of a second MspI site which is conserved in the H-ras 1 nucleotide sequence. The second restriction site provides a control for efficient enzyme digestion as well as discrimination of RFLP products from undigested PCR products $(6,7)$. Preservation of both restriction sites in RT-PCR products as well as in the PCR products allows detection of expression of normal and activated $\mathrm{H}$-ras 1 transcripts.

The two rodent cell lines employed as controls in this work, behaved exactly as expected according to the type of human $\mathrm{H}$-ras 1 introduced into their genomes. RFLP analysis at genomic and transcriptional level provided equivalent results.

Recently it has been shown that structural modifications are followed by allelic imbalances (5) or altered ratio of expression between normal and mutant $\mathrm{H}$-ras 1 transcripts (6). In order to evaluate such quantitative alterations both at DNA and RNA level we have designed an internal competitor with a different size, to be coupled to amplification reactions. The internal control was cloned in an expression vector, to provide cRNA transcripts suitable to be used in the $\mathrm{RT}$ reaction step. The use of an internal competitor in the RT step prevides more accurate control for the overall reaction efficiency during quantification reactions. On the other hand the construct itself can be employed in DNA quantifications of H-ras 1 gene copies. The comparison between gene copy number and transcriptional expression level could provide answers for the expressional activation of H-ras 1 .

The cell lines used in this study were previously known to harbour high copy numbers of normal and mutant $\mathrm{H}$-ras 1 gene respectively $(8,9)$. For this reason these cell lines were suitable to create the situation where high copy numbers present in the genome result in high levels of gene expression.

We performed the quantitative assays described to test the efficacy and accuracy of competitive (RT-)PCR estimations. 
Quantitative analysis of data gathered from the cell line measurements show a linear relationship between the ratio of amplified products and the initial concentrations of the substrates. This is confirmed by the high values of the correlation coefficient $\left(\mathrm{R}^{2}=0.98-0.99\right)$ obtained after regression analysis of each set of data. Theoretical analysis however argues that this kind of relationship is not sufficient for the product ratio to reflect the real ratio between the target and competitor molecule (13). According to the mathematical modelling of the reaction equation, in addition to the linear relationship of the data it is necessary for the slope of the equation to be equal to unity (13). This results in minimisation of error estimation of initial concentrations after extrapolating the product ratio on the standard curve (13).

We have obtained quantitative data sets for varying PCR cycles which invariably show a linear relationship, but usually with a slope deviating from unity. In our experience the closest values to unity of the slope were obtained after low PCR cycling numbers $(\leq 25)$, although the accumulated PCR products were scarcely seen on ethidium bromide stained agarose gels (15), making direct densitometric analysis of the gels difficult (16). For this reason we chose direct densitometric analysis of silver stained polyacrylamide gels $(11,16)$.

The standard curves describing the linear quantitative relationship of the serial dilutions series versus product ratios exhibited an identical slope at DNA or RNA level between the two cell lines respectively. This can be explained by the same primer efficiency during assay performance of either RT-PCR or PCR, for each cell line respectively. This parallel shift between the data of the two cell lines is in agreement with theoretical considerations (13).

The most accurate measurements were obtained by quantification closer to the equivalence points (13). Increasing the quantification range around the stoichiometric point preserved linearity but altered the slope of the curve (13). This was observed in the case of RNA quantitation where the total RNA varied over a 20-fold range in contrast to DNA where a $10^{4}$-fold range was used. Furthermore PCR amplification of cDNA has been reported to be less efficient than DNA amplification (17).

Finally, we draw attention to the experimental conditions necessary to perform competitive assay quantification, since this approach has been described as the most accurate approach to PCR quantitation (18). Experimental conditions need to be established carefully and standardised for each specific application to satisfy the theoretical conditions inferred by mathematical analysis of competitive quantitation. These should include competitor design and experimental conditions during PCR (or RT-PCR) amplification.

\section{Acknowledgements}

We would like to thank Dr J. Taylor-Papadimitriou and Professor J.C. Neil for comments and critical reading of the manuscript.

\section{References}

1. Spandidos DA and Lang JC: In vitro cell transformation by ras oncogenes. CRC Crit Rev Oncog 1: 195-209, 1989.

2. Spandidos DA and Anderson MLM: Oncogenes and oncosuppressor genes: their involvement in cancer. J Pathol 157: 110, 1989

3. Brown K. Buchmann A and Balmain A: Carcinogen-induced mutations in the mouse $\mathrm{c}-\mathrm{H}-\mathrm{ras}$ gene provide evidence of multiple pathways for tumour progression. Proc Natl Acad Sci USA 87: 538-542, 1990.

4. Miyamoto S, Sukumar S, Guzman RC, Osborn RC and Nnandi S: Transforming c-Ki-ras mutation is a preneoplastic event in mouse mammary carcinogenesis. Mol Cell Biol 10: 1595-1599. 1990.

5. Bremmer R and Balmain A: Genetic changes in skin tumour progression: correlation between presence of a mutant ras gene and loss of heterozygosity on mouse chromosome 7. Cell 61: 407-417, 1990

6. Kotsinas A, Spandidos DA, Romanowski P and Wyllie AH: Relative expression of wild-type and activated Ki-ras 2 oncogene in colorectal carcinomas. Int J Oncol 3: 841-845, 1993.

7. Jiang W, Kahn SM, Guillen JG, Lu SH and Weinstein IB: Rapid detection of ras oncogenes in human tumours: applications to colon, esophageal and gastric cancer. Oncogene 4: 923-928. 1989.

8. Spandidos DA and Wilkie NM: The normal human $\mathrm{H}-$ ras 1 gene can act as an onco-suppressor. Br J Cancer 58: 67-71, 1988.

9. Spandidos DA: Mechanism of carcinogenesis: the role of oncogenes, transcriptional enhancers and growth factors. Anticancer Res 5: 485-498, 1985.

10. Laird PW, Zijderveld A, Linders K, Rudnicki MA, Jaenisch R and Berns A: Simplified mammalian DNA isolation procedure. Nucleic Acids Res 19: 4293, 1991.

11. Cantu GR and Nelson JW: Densitometry: Modern approaches advance an established technique. BioTechniques 16: 322-327. 1994.

12. Galea E and Feinstein DL: Rapid synthesis of DNA deletion constructs for mRNA quantitation: analysis of astrocyte mRNA. PCR Meth Appl 2: 66-69, 1992.

13. Raeymaekers L: Quantitative PCR: theoretical considerations with practical implications. Anal Biochem 214: 582-585, 1993.

14. Capon DJ, Chen EY, Levinson AD, Seeburg PH and Goeddel DV: Complete nucleotide sequence of the T24 human bladder carcinoma oncogene and its normal homologue. Nature 302: 33 37, 1983.

15. Murphy LD, Herzog CE, Rudick JB, Fojo AT and Bates SE: Use of the polymerase chain reaction in the quantitation of $m d r-1$ gene expression. Biochemistry 29: 10351-10356, 1990.

16. Bouaboula M, Legoux P, Pességué B, Delpech B, Dumont X, Piechaczyk M, Cassellas P and Shire D: Standardization of mRNA titration using a polymerase chain reaction method involving co-amplification with a multispecific internal control. J Biol Chem 267: 21830-21838, 1992.

17. Rappolee DA, Wang A, Mark D and Werb Z: Novel method for studying mRNA phenotypes in single or small numbers of cells. J Cell Biochem 39: 1-11, 1989.

18. Foley KP, Leonard MW and Engel JD: Quantitation of RNA using the polymerase chain reaction. Trends Genet 9: 380-385. 1993. 